\title{
The Paradiplomatic Role of the ConIFA in Promoting Self-Determination of Marginalized Entities
}

\author{
Ario Bimo Utomo \\ Universitas Pembangunan Nasional "Veteran" Jawa Timur
}

\begin{abstract}
ABSTRAK
The purpose of this paper is to apply the paradiplomacy framework in exploring the role of NGOs in promoting the issue of marginalized peoples. More specifically, it highlights the Confederation of Independent Football Association (ConIFA), an international football governing body comprising minority peoples, stateless nations, and regions which are unrecognized by the Federation Internationale de Football Association (FIFA). The author attempts to discuss ConIFA's ability in voicing the issue of self-determination concerning its members, which are mainly sidelined in the mainstream international affairs. This paper discusses two questions: (1) does ConIFA qualify to be regarded as a paradiplomatic actor? If yes, in what ways? and (2) to what extent does ConIFA advocate the issue of self-determination of its members? In so doing, the researcher first studies the nature of ConIFA through its own constitution as well as examining its activities through various sources. Second, the author also utilizes core concepts on paradiplomacy to seek in which category does ConIFA's activities fall into. The findings suggest that ConIFA qualifies as a paradiplomatic actor in the sense that it has two forces: horizontal and vertical. Horizontally, it platforms its members to interact with like-minded counterparts through numerous activities. Vertically, ConIFA also possesses a comparative advantage to reach a wider audience by framing the issue through sport. However, the study also indicates that while self-determination is promoted through ConIFA, the organisation does not possess enough political capacity to facilitate a deeper advocacy, thus making its paradiplomatic activities mainly fall into the cultural category.
\end{abstract}

Keywords: ConIFA, football, nationalism, paradiplomacy, self-determination, sport

Tujuan dari makalah ini adalah untuk mempromosikan peran NGO dalam mempromosikan masalah masyarakat yang terpinggirkan. Secara khusus menyoroti Konfederasi Asosiasi Sepak Bola Independen (ConIFA), yang mengatur badan internasional yang terdiri dari orang-orang minoritas, negara tanpa kewarganegaraan, dan wilayah yang tidak diakui oleh Federasi Internationale de Football Association (FIFA). Penulis membahas masalah penentuan nasib sendiri ConIFA mengenai anggotanya, yang sebagian besar dikesampingkan dalam urusan internasional arus utama. Makalah ini membahas dua pertanyaan: (1) Apakah ConIFA memenuhi syarat untuk menjadi aktor paradiplomatik? Jika ya, dengan cara apa? dan (2) sampai sejauh mana ConIFA mendukung masalah penentuan nasib sendiri anggota? Melalui hal tersebut, pertama peneliti akan mempelajari konstitusi dasar serta memeriksa kegiatan ConIFA melalui berbagai sumber. Kedua, penulis juga menggunakan konsep inti tentang paradigma untuk mencari inti dari kegiatan tersebut. Temuan menunjukkan bahwa kualifikasi sebagai aktor paradiplomatik dalam arti memiliki dua kekuatan: horisontal dan vertikal. Secara horizontal, ini platform untuk berinteraksi dengan rekan-rekan yang berpikiran sama melaluiberbagaikegiatan. Secaravertikal,ConIFAjugamemilikikeunggulan komparatif untuk audiens yang lebih luas dengan membingkai masalah melalui olahraga. Namun, studi ini juga menemukan bahwa walaupun self-determination bisa dipromosikan melalui ConIFA, organisasi ini tidak memiliki kapabilitas politik untuk melakukan avdokasi yang mendalam. Kondisi ini kemudian membuat aktivitas paradiplomasi jatuh ke dalam kategori kultur.

Kata-kata kunci: ConiFA, sepak bola, nasionalisme, paradiplomasi, penentuan nasib sendiri, olahraga 
Sport has been an integral activity of humankind as it is closely related to the healthy lifestyle, for a long time. History also implied that the oldest sports activity dated back to 3.000 years ago, when people utilized sport to prepare their physique for exhausting activities such as war and hunting (Bellis 2018). Sport was first known as an international competition when the Ancient Greeks first popularized sport as a competition played by city-states (polis) through the Ancient Olympics which began circa 776 BC. It was the root of the modern Olympics Games which we know today. Since then, the sport has been seen not only as a natural activity to keep one's well-being, but also a competition where most will find a sense of achievement when winning it.

When sport is intertwined with international politics, it created a new phenomenon when a nation's performance in sport is regarded as the reflection of its power. In other words, sport is now also a source of soft power which can add some value toward the national reputation, a clear indication of a nation's power strength and how it stands in the global arena (Wang 2006, 92). Therefore, it is understandable if countries put some priority when it comes to developing the sport in their own country. For the citizens, on the other hand, the national athletes are now also put in the same esteem as national heroes. They find pride in supporting the people who compete for their nation, pretty much aligns with the conception of imagined community coined by Anderson (1983). Sport is kind of universal language, which knows no boundaries, has made people revert to it as a way to build common understandings. Besides, some scholars have highlighted sports diplomacy as one of the contemporary forms of nonconventional diplomacy (Ndlovu 2010; Nygård and Gates 2013; Deos 2014; Redeker 2008).

One of many sports which the world knows is the association football (for the sake of simplicity, this article will use "football" to refer to the aforementioned sport and not the other variants). It is widely considered the most popular sport on earth (Boudway 2018). According to the official website of Fédération Internationale de Football Association (FIFA), the contemporary form of football was generated in 1863 when rugby and association football "branched off on their different courses" in England and the country created its Football Association, the first ever football-governing association in the world (FIFA n.d.). However, FIFA also acknowledges that the oldest form of football was initially found in the Chinese Han Dynasty between the $2^{\text {nd }}$ or the $3^{\text {rd }}$ century through a sport called tsu chu, the game of kicking a leather ball filled with feather into a small opening. The sport was known as an exercise for military personnel (FIFA n.d.).

Shifting our discussion to some stateless nations and sub-national entities, things are rather different under a condition where there has been a lack of international recognition and sovereignty. In this case, sport can also be used as a means to express self-determination sentiments. As football is the most popular sport on earth, it is reasonable that the history of this sport has witnessed some dynamics of nationalistic struggles within. Practically, that kind of sentiment is facilitated through the emergence of international friendlies among the unrecognized states as well as the creations of unofficial football associations which govern that kind of entities. This article will discuss the latter example by providing the case study of ConIFA (Confederation of Independent Football Associations) as a media for the to channel the self-determination. In answering the question, the author explores several important legal documents related to the case study such as ConIFA Statute, the FIFA Statute, and ConIFA Activity Reports. On the other hand, the author also employs scholarly sources to relate to the concept of paradiplomacy and its application in the case study. 


\section{ConIFA and Their Activities}

Confederation of Independent Football Associations (ConIFA) is a non-profit, volunteerbased, football organization based in Sweden which aims to support representatives of international football teams from nations, de-facto nations, regions, minority peoples and sports isolated territories (ConIFA 2017a). The federation was established on June $7^{\text {th }}$ 2013. In their constitution, ConIFA states that the overall aim is raising people through football which includes: (1) strengthen people, (2) strengthen identity of people, for nations, minorities, and isolated territories, (3) respect differences, (4) contribute to world peace (ConIFA 2013b, 1).

The membership of ConIFA is quite unique. Unlike FIFA which requires their members to be "independent states recognized by the international community" or, in some cases, "regions which has not yet gained independence" which are authorized by its host country to apply for membership (FIFA 2008), ConIFA requires their member to be representing nations, minorities, or geographically or sportingly isolated territories which are still yet to be affiliated by FIFA (ConIFA 2013b, 1). As for September 2018, there have been 48 members of ConIFA, consisting of entities originating from Europe, Asia, North America, Africa, as well as Oceania.

The organization has three forms of membership: effective, honorary, and sympathiser. Each of the forms has its own benefits and obligations. The effective membership comprises football associations, clubs, players, and individuals associated with the represented entity. The effective members are subject to annual membership subscription, however, they have the right to vote in the General Meetings (10 votes for the football associations and clubs and 1 vote for players and individuals). Honorary members are people who have been considered worthy of it, either by their function or by the good turns that they have done or they do to the football of Peoples, Nations, Minorities and geographically or sportingly isolated territories populations (ConIFA $2013 \mathrm{~b}, 3)$. They do not possess the obligation to pay annual member subscription, yet they also do not have the right to vote in the General Meetings. Honorary members are still able to take part in the meeting as consultative advisors. Honorary members can also apply for an effective membership so they can vote in the General Meetings. Lastly, sympathizer members are people or companies who merit the award through their donation or legacy toward the ConIFA.

Since 2014, ConIFA has been conducting two forms of competition: the ConIFA World Cup and the ConIFA European Cup. So far, the ConIFA World Cup has been held three times $(2014,2016,2018)$. The ConIFA European Cup, on the other hand, has been held twice (2015 and 2017) with the upcoming 2019 edition as the expected third edition. The last 2018 ConIFA World Cup was held in London with Barawa Football Association acted as the host. The ConIFA regulation does not obligate the host country to hold the competition in their home soil; the hosts are only responsible for organizing the competition (ConIFA 2017e). Therefore, it is possible for the Barawa Football Association, which represents a region in southern Somalia, to organize the World Cup in London through the help of the Somali diaspora.

ConIFA itself is not the first organization to manage non-FIFA football. Previously, there was a similar organization called the New Federation Board which existed from 2003 to 2013 when it was declared defunct (Kaper 2016). NF-Board organised another competition called the VIVA World Cup, which was obviously a spin-off of the popular 
FIFA World Cup. VIVA World Cup series was held five times (2006, 2008, 2009, 2010, 2012). Since the defunct of NF-Board, ConIFA took over as the new spearhead in advocating football rights for marginalised entities.

Activities of ConIFA do not only joined by the individuals which are affiliated to the marginalized entities. The organization also opens themselves to the public through sponsorships. In their website, ConIFA invites everyone to become the sponsor of this organization. Becoming the sponsor, as the organization claims, is a "unique opportunity to take a strong position in the football world outside FIFA." (ConIFA 2017d). Paddy Power, a betting company based in Ireland, is by far the most highprofile company to sponsor ConIFA where they contributed as the title sponsor of the 2018 World Cup. As quoted by SBC News, Paddy Power was willing to do such unusual decision as they wanted to support the rebels and wildcards of world football who FIFA refuse to recognize (Menmuir 2018).

Besides of holding football competitions, ConIFA also held several other non-footballing activities which have the same goal of promoting identities of the represented entities. In 2013, for instance, the organization conducted the ConIFA Youth Exchange which was participated by 60 European youths, intended to promote intercultural learning and dialogue. The event was followed by a cultural village which contained exhibitions, presentations, and discussions from the respective participants (ConIFA 2013a). ConIFA has also done several important visits. In 2015, the organization did six institutional visits, one of which is the visit to Brussels by the President and the Vice President in order to seek for further relation with the European Union (ConIFA 2015). The 2017 was even more productive for ConIFA. According to the report, there were 19 different activities including the creation of No Limits movement, a branch of ConIFA which organizes football for disabled people. Another notable achievement was in October when ConIFA was accepted as a member of the International Sports and Culture Association (ISCA). Besides that, ConIFA also did some institutional visits to Ireland, Cyprus, Italy, Zimbabwe, United Kingdom, Zambia, Kyrgyzstan, Germany, Monaco, France, and Australia (ConIFA 2017b).

Even though their activities are closely related to the promotion of marginalized peoples, nations, and regions, ConIFA asserts that their activities have nothing to do with politics. They agree with FIFA's message to separate politics from football. Thus, instead of promoting any political status, they are more interested in promoting people and letting them play football under the identity which is not recognized under the FIFA-sanctioned competition. ConIFA claims that they are "100 percent politically neutral" and only aims to educate the world about the existence of the members. In other words, ConIFA only offers a stage where each of the members can be "an ambassador of his nation of his people" (ConIFA 2017c).

\footnotetext{
"We don't support any status, including status quo. Tibetans are Tibetans, no matter which passport they hold or which border surrounds them. We allow them to play football as Tibetans, but don't allow them to promote independence or a union with anyone." (Quoted from ConIFA's official Twitter account, June 23, 2018)
}

However, obviously, it remains difficult to separate the political dimension from ConIFA's activities. With some of the members do belong to separatist movements such as Northern Cyprus, Uyghur, Tibet, and Abkhazia, the display of political aspirations can't be simply disregarded (Ginell 2018). After all, recognition is an essential element 
of every pursuit of self-determination. In this case, ConIFA has been subtly effective in channeling such motivations through football despite not explicitly advocating political independence. This ambiguous stance by ConIFA has met with suspicions views by several actors, particularly from sovereign states whose sub-national entities participate in the organization as members. One instance is how the Ukrainian government called for an investigation of "possible separatists' movement" in the Karpatalya team. The Karpatalyan team, who won the ConIFA World Cup after defeating Nothern Cyprus on penalties, consist of ethnic Hungarians residing in Ukraine. Sports Minister Ihor Zhdanov label the participation of Karpatalya as "sporting separatism", the Ukrainian Football Federation follows suit by declaring that they might ban the members of the Karpatalyan team from competing in their sanctioned matches (Williams and Polityuk 2018). Another example is how the Sri Lankan government responded to the participation of Tamil Eelam, a member federation representing the Tamil people. Sri Lanka objects the inclusion of Tamil Eelam under the basis that such entity has never existed in the country. Moreover, the name is also used by the now-defunct Liberation Tigers of Tamil Eelam, an organization labeled as terrorists. The Sri Lankan government says that by recognising Tamil Eelam, ConIFA will "promote and support divisive, separatist tendencies as well as violence in many countries including Sri Lanka" (Griffiths 2018).

From the aforementioned explanations, we can observe that ConIFA's activities go beyond the scope of football. As an international actor, ConIFA delivers an unconventional approach which somehow challenges the status-quo narrative of the international football. Differing from FIFA which governs sovereign entities, ConIFA has instead provided a venue for actors which otherwise would be unrecognized within the current nation-state based international regime. Albeit indirectly, we can see some elements of diplomacy in their activities, one relevant way to see this is through the lens of paradiplomacy.

\section{Paradiplomacy and Self-determination}

Thetopiconhowsubnationalentitiesbehaveininternational relations, orparadiplomacy, is a relatively thought-provoking subject in the current era of globalization. Cornago (2013) describes is as a "vibrant" object of study yet remains "peripheral" as it seems to have less attention in the mainstream discourse on diplomacy. There are at least two factors which contribute to this lack of attention. First is the prevailing state-oriented paradigm in viewing the international politics. Second is the ambiguous nature on how to rigidly define the "subnational entities" as there are myriads of political entities which are subordinates of the current nation-states, yet having different degrees of autonomy and level of governance. Cities, provinces, autonomous republics, oblasts, cantons, prefectures, and more of them are essentially "subnational" but we certainly cannot throw them into the same basket. This case is even more perplexing when we put several entities such as breakaway states and separatist groups into the equation. Paradiplomacy, therefore, is a global reality in our contemporary world which needs further attention.

Paradiplomacy is coined as a compound word for "parallel diplomacy", indicating that the activity should always be distinguished from any other forms of diplomacy (Soldatos 1990). Roughly, paradiplomacy can be understood as the involvement of 
subnational government external affairs in international relations, a domain which is more popularly understood as state-dominated. Throughout its development, paradiplomacy has been used interchangeably with a number of other terms such as "micro diplomacy", "protodiplomacy", "constituent diplomacy", and "multilayered diplomacy". However, as those terms have not been rigidly-defined as the original concept of paradiplomacy, it can be problematic when those definitions shift meanings and thus leads to a confusion when discussing different contexts (Kusnetzov 2014). Moreover, "parallel" does not always indicate that paradiplomacies are aligned with the host states' interests. In many cases, paradiplomacy is used as a product of opposition toward the central government's decisions. Therefore, it is important for scholars to clarify the intended meaning of the term in their works in order to get the most relevant contextual definition on paradiplomacy.

As much as its disputed definition, there have been some disagreements about the exact time paradiplomacy officially emerged as a new focus of academic discourse. Kusnetzov (2014) argues that the initial use of "paradiplomacy" in an academic article can be traced back even further in 1961, when Rohan Butler published a monograph under the title "Paradiplomacy". In this first attempt to define the concept, paradiplomacy was defined as a set of secret diplomatic activities which may take place under the table, as opposed to the official diplomatic acts. However, Kusnetzov acknowledges that Butler's definition on paradiplomacy is problematic, as it shows no substantial differences from the ancient diplomatic practices which employed elements of secrecy in them. Another view argues that paradiplomacy, as we understand today, slides into the academic discussions in the 1980's following the development of the study on federalism (Aguirre 1999). The notable mention of "paradiplomacy", which has redefined the way it is approached now, was done by the work of Duchacek (1984) in Publius. In his article, he translates paradiplomacy as an umbrella term for transborder regional activities and global micro diplomacies, putting subnational governments "into direct contact with foreign national and constituent governments" (Duchacek 1984, 5).

Responding to the aforementioned problem with definitions, how do we distinguish one paradiplomacy from another? And more importantly, what category of paradiplomacy can explain the involvement of subnational entities in the case of ConIFA? A relatively convenient way is viewing through the lenses of grand International Relations theories. Kaminski (2018) argues that three big theories of International Relations: liberal, realist, and constructivist have their takes in explaining the logic of paradiplomacy.

According to liberals, paradiplomacy is a consequence of the changing nature of international politics. This view stems from the work of Keohane and Nye about the shifting from a state-centric world to a multicentric world where multinational corporations (MNC) and nongovernmental organization (NGO) emerge as new actors (Nye and Keohane 1971). On the other hand, such occurrence has created a distinction between "high" politics (affairs related to state security) and "low" politics (domestic issues other than security such as economy and education). As the result, paradiplomacy diminishes the trend of interstate relations. On the other hand, local and regional entities are now more aware of their existence on the global stage, leading to their involvement in international affairs.

Realists, however, disagree with this logic of paradiplomacy. According to realists, paradiplomatic activities do not reflect the obsolescence of the state-centric world 
order. Rather, paradiplomacy is the continuation of the foreign policy by central governments done through their regional authorities (Kusnetzov 2014). By this definition, paradiplomacy is "just an instrument in a state's foreign policy toolbox" where the participation of the sub-national entities are subject to approval by the central governments (Kaminski 2018).

In contrast to the previous arguments, the constructivists argue that paradiplomacy is a form of "identity-constructing" in the global system. Therefore, paradiplomacy in constructivists' sense also entails the elements of sovereign statehood. Sub-national entities use paradiplomacy to "signal" the world about their existence, which in return it is expected that the other entities would reciprocate by recognizing the signaling entity as an international actor (Sharafutdinova 2003). Constructivists reject the idea that paradiplomacy is a mere response to globalization (liberal) or an instrument of central government's foreign policy (realism). Lecours also argues in favor, saying that nationalism "is the single most important variable conditioning paradiplomacy" (Albina 2010). On a similar note, Kusnetzov (2014) outlines that one dimension of paradiplomacy is the separatist dimension, through which one can examine "the struggle for statehood and search for international recognition by subnational governments" (Kusnetzov 2014, 7). This kind of paradiplomacy highlights a problem when the territorial sovereignty of the nation-states is challenged with the rising demand for autonomy of their consittuents. This problem occurs as a consequence of the conflicting logic between the constitutive and declarative doctrines of statehood. According to the constitutive doctrine, a state is recognized as a subject of the international law when recognized by the other states. On the other hand, the more specific declarative doctrine stipulates that there are four criteria of political entities to be called states: (1) a clearly defined territory, (2) a permanent population, (3) a running government, and (4) a capability to interact with other states in the international community. While both doctrines should, in theory, reinforce each other; in reality it is not as ideal as it is supposed to be. Various entities which declaratively qualify for statehood remain aliens in international politics due to the lack of recognitions by the international community (Kusnetzov 2015, 89). The constructivist dimension of paradiplomacy, therefore, deals with filling this gap by advocating the identities of such unrecognized entities to eventually gain more stature in the international politics.

\section{ConIFA as a Paradiplomatic Actor}

From the previous sections, we can conclude that the case of ConIFA belongs to the constructivist dimension of paradiplomacy. From the ConIFA case study, we can see quests for recognition as the members' background, exclusive memberships for entities not belonging to FIFA, and cultural campaigns aside footballing activities as the defining elements in this case of paradiplomacy. Yet, we have to understand that ConIFA is not a paradiplomatic actor in its truest sense, as ConIFA is not a subnational entity and the definition of paradiplomacy is more accurately applied to sub-national actors conducting international affairs in simulation to the sovereign counterparts. However, that does not signify that the role of ConIFA is any less important. The author argues that there are two paradiplomatic roles which ConIFA possesses. First, it has created a supra-structure which enables the sub-national entities to interact and thus channeling their self-determination interests to the world. This is not strange in the contemporary world, as paradiplomacy has become more and more organized by 
a range of agreements and organizations. As the NF-Board failed, ConIFA has held the supreme advantage as the leading organization of football paradiplomacy. The author argues that this form of paradiplomacy falls somewhere between the category of "sovereign paradiplomacy" and "single-themed paradiplomacy" coined by Tavares (2016) where despite the actors hold some degree of political aspirations, cultural education is more prioritized. This kind of paradiplomacy also enabled its actors to play within the safe area, minimizing the risks of having demonized for separatism by their host states without compromising the benefits of having international exposure with the like-minded members.

The second capability of ConIFA is its ability to project the issue through a less controversial frame. In the constructivists view, ConIFA is a platform where the process of identity-creation and intersubjectivity is facilitated in an extremely specific manner, football. The organization, declaring itself as apolitical, has been cautious in advocating common understanding about the debated identity of its members. In a piece of literature, Xifra (2009) coined the concept of "sports country" which mainly argues that sport has the capability to construct a national image of states-including the ones which are still yet to be recognized by international organizations. Sport can be used as a public diplomacy tool showing that a certain entity exists. He uses the case study of the Catalonian Autonomous Republic, a region under the sovereign Spanish state, which has relatively gained a reputation of a "sports country" where its soft power is reflected through its brand as a region with a successful prioritization of sport-, especially football. One successful example is the Barcelona Football Team, which he calls as "without a doubt the best-known Catalan product abroad". The success in the image-building as a sports country can be an alternative form of soft power which can develop one's diplomatic stature in the international stage. In this case, ConIFA has a role in helping their members build their images as "sports entities" whose identity lives on despite the lack of external recognitions. Through their myriad of activities which does not only include football competitions, ConIFA, in Xifra's words, has the ability to "develop public relations activities to build an international reputation of regions" (Xifra 2009). Having said this, the author affirms that ConIFA also has the vertical force as the lighthouse which can project the image of its member states to the world.

\section{Conclusion}

Globalization is a powerful force which reshapes the way we perceive nations today. As globalization increases the interaction between people, it has also increased the awareness of marginalized groups to start advocating identities which they associate themselves with. The problem occurs when such identities are not recognized in the international stages due to the remaining state-centric view of the world. In this case, sport has tried to fill the gap. Its universal nature has made it an effective force in promoting aspirations which, through conventional means, cannot be easily expressed. Through the case study of ConIFA, we can examine that the organization has provided a paradiplomatic role in advancing the self-determination of its members, which mostly belong to marginalized groups such as de facto states, nations, oppressed peoples, and isolated territories. Using football as the frame of their activities, ConIFA has been quite effective in promoting the identity of those entities by allowing them to compete in football matches under the flags which they have more sense of belonging towards. 
The author argues that as a paradiplomacy facilitator, ConIFA has two forces. Horizontally, ConIFA has the ability to become a supra-structure for the members to communicate and build a sense of intersubjectivity among each other. Vertically, ConIFA is benefitted by their specific focus so that they can help the members project the "sports countries" image which might develop the members' diplomatic statures. This paradiplomacy, nevertheless, will have both its potentials and shortcomings. For the member states, such form of paradiplomacy will enable them to, albeit narrowly, assert their identity which otherwise will be outlawed under the regime which favours the status-quo. However, as ConIFA remains an apolitical organization, it is, therefore, too soon to argue that the paradiplomacy facilitated by ConIFA will necessarily lead to anything beyond football.

\section{References}

\section{Books and Chapter in Books}

Cornago, Noe. 2013. Plural diplomacies: Normative predicaments and functional imperatives. Leiden: Martinus Nijhoff Publishers.

Duchacek, Ivo. 1988. "Multicommunal and Bicommunal Polities and Their International Relations." In Perforated Sovereignties and International Relations: Trans-Sovereign Contacts of Subnational Governments, edited by Ivo Duchacek, Daniel Latouche, and Gareth Stevenson. Westport: Greenwood Press.

Kaminski, Tomasz. 2018. "Paradiplomacy - Discourse Analysis and Research Conceptualisation.” In Paradiplomacy in Asia: Case Studies of China, India, and Russia, edited by Malgorzata Pietrasiak, Grzegorz Bywalec, Tomasz Kaminski, Dominik Mierzejewski, and Michal Slowikowski. Lodz: Lodz University Press.

Kusnetzov, Alexander. 2014. Theory and Practice of Paradiplomacy: Subnational Governments in International Affairs. New York: Routledge.

Soldatos, Panayotis. 1990. "An Explanatory Framework for the Study of Federated States as Foreign-Policy Actors.” In Federalism and International Relations, edited by Hans Michelmann and Panayotis Soldatos Oxford: Oxford University Press.

Tavares, Rodrigo. 2016. Paradiplomacy: Cities and States as Global Players. New York: Oxford University Press.

\section{Journals and Online Journals}

Aguirre, Iñaki. 1999. "Making Sense of Paradiplomacy? An Intertextual Enquiry about a Concept in Search of a Definition." Regional and Federal Studies. https://doi.org/10.1080/13597569908421078.

Albina, Elena. 2010. “The External Relations of Tatarstan: In Pursuit of Sovereignty, 
The Paradiplomatic Role of the ConIFA in Promoting Self-Determination of Marginalized Entities

or Playing the Sub-Nationalist Card?” The Hague Journal of Diplomacy. https://doi.org/10.1163/1871191x-05010105.

Deos, Anthony. 2014. "Sport and Relational Public Diplomacy: The Case of New Zealand and Rugby World Cup 2011." Sport in Society. https://doi.org/10.1080/ 17430437.2013 .856588 .

Duchacek, Ivo. 1984. "The International Dimension of Subnational SelfGovernment.” Publius, https://doi.org/10.1093/oxfordjournals.pubjof.a037513

Ndlovu, Sifiso Mxolisi. 2010. "Sports as Cultural Diplomacy: The 2010 FIFA World Cup in South Africa's Foreign Policy.” Soccer \& Society. https://doi. org/10.1080/14660970903331466.

Nye, Joseph S, and Robert O Keohane. 1971. "Transnational Relations and World Politics: An Introduction.” International Organization. https://doi.org/ doi:10.1017/Soo20818300026187.

Nygård, Håvard Mokleiv, and Scott Gates. 2013. "Soft Power at Home and Abroad: Sport Diplomacy, Politics and Peace-Building." International Area Studies Review. https://doi.org/10.1177/2233865913502971.

Redeker, Robert. 2008. "Sport as an Opiate of International Relations: The Myth and Illusion of Sport as a Tool of Foreign Diplomacy." Sport in Society. https://doi. org/10.1080/17430430802019482.

Sharafutdinova, Gulnaz. 2003. "Paradiplomacy in the Russian Regions: Tatarstan's Search for Statehood.” Europe - Asia Studies. https://doi.org/10.1080/0966813 032000084028.

Wang, Jian. 2006. "Managing National Reputation and International Relations in the Global Era: Public Diplomacy Revisited.” Public Relations Review. https://doi. org/10.1016/j.pubrev.2005.12.001.

\section{Online Articles}

Bellis, Mary. 2018. "The History of Sports, From Ancient Times to Modern Day." ThoughtCo. 2018. https://www.thoughtco.com/history-of-sports-1992447.

Boudway, Ira. 2018. "Soccer Is the World's Most Popular Sport and Still Growing." Bloomberg. 2018. https://www.bloomberg.com/news/articles/2018-06-12/ soccer-is-the-world-s-most-popular-sport-and-still-growing.

Ginell, Luke. 2018. "ConIFA May Be Apolitical, but It Gives a Voice to Causes Straining to Be Heard.” These Football Times. 2018. https://thesefootballtimes. co/2018/05/14/conifa-may-be-apolitical-but-it-gives-a-voice-to-causesstraining-to-be-heard/.

Griffiths, Ryan. 2018. "Geopolitics and the CONIFA World Cup.” IPI Global Observatory. 2018. https://theglobalobservatory.org/2018/07/geopolitics- 
conifa-world-cup/.

Kaper, Joris. 2016. "Die Andere Voetbalbond: Van de NF-Board Naar de ConIFA." Staantribune. 2016. https://staantribune.nl/die-andere-voetbalbond-van-de-nfboard-naar-de-conifa/.

Menmuir, Ted. 2018. "Paddy Power Sponsors ConIFA ‘Rebels' World Cup.” SBC News. 2018. https://www.sbcnews.co.uk/europe/2018/o3/23/paddy-powersponsors-conifa-rebels-world-football-cup/.

Williams, Matthias, and Pavel Polityuk. 2018. "Ukraine Accuses Soccer Team of 'Supporting Separatism." Reuters. 2018. https://www.reuters.com/article/ us-ukraine-soccer-investigation/ukraine-accuses-soccer-team-of-supportingseparatism-idUSKBN1J72BH.

Xifra, Jordi. 2009. "Building Sport Countries' Overseas Identity and Reputation: A Case Study of Public Paradiplomacy.” American Behavioral Scientist. https:// doi.org/10.1177/0002764209347627.

ConIFA. 2013a. “Activity Report 2013.” Cologne. http://www.conifa.org/sites/ default/files/media/AGM 2014/Official docs/CONIFA ACTIVITY REPORT.pdf.

--—. 2013b. ConIFA Constitution. Sweden. http://www.conifa.org/en/wp-content/ uploads/2015/11/conifa-constitution.pdf.

-—-. 2015. “Activity Report 2015.” Bergamo. http://www.conifa.org/en/wpcontent/uploads/2016/o1/Activity-Report-2015.pdf.

-—-. 2017a. "About Us.” ConIFA. 2017. http://www.conifa.org/en/about-us/.

- - . 2017b. "Activity Report 2017." Kyrenia. http://www.conifa.org/en/wpcontent/uploads/2017/12/CONIFA-Activity-Report-2017.pdf.

-—-. 2017c. "FAQ." ConIFA. 2017. http://www.conifa.org/en/about-us/faq/.

-—-. 2017d. "Get Involved.” ConIFA2. 2017. http://www.conifa.org/en/contact/ get-involved/.

--—. 2017e. "World Football Cup Qualification System.” ConIFA. 2017. http://www. conifa.org/en/wfc-2018/qualification/world-football-cup-qualification-system/

FIFA. n.d. "History of Football - The Origins." FIFA. https://www.fifa.com/aboutfifa/who-we-are/the-game/index.html.

---. 2008. FIFA Statutes: Regulations Governing the Application of the Statutes. https://resources.fifa.com/mm/document/affederation/generic/01/o9/75/14/ fifa_statutes_072008_en.pdf. 
The Paradiplomatic Role of the ConIFA in Promoting Self-Determination of Marginalized Entities 